\title{
CLIMAT AND OROGRAPHIC IMPACT ON VOLUME INCREMENT OF THE FORESTS OF BEECH, FIR AND SPRUCE ON LIMESTONE AND DOLOMITE IN FEDERATION OF BOSNA AND HERZEGOVINA
}

\author{
Uticaj klime i orografskih faktora na zapreminski prirast \\ u šumama bukve i jele sa smrčom na krečnjacima i dolomitima \\ u Federaciji Bosne i Hercegovine
}

\author{
Ahmet Lojo ${ }^{1}$
}

\begin{abstract}
Research results of the stand volume increment changes in mixed forests of beech, fir and spruce on limestone and dolomite in Federation of Bosnia and Herzegovina $(\mathrm{FB} \& \mathrm{H})$, is presented in this work. Impact of different factors to volume increment value was investigated: habitat quality, values - indicators of structural characteristics particular forest stands, and orographic characteristics if the terrain. Impact of climate differences was investigated trough position of the forests stands in particular ecological-vegetation regions in B\&H. Research was done on example of 799 forest stands, trough complex methods of multiple regression analyses, and variance analyses (ANOVA), The results shows that volume increment of the forest stands, besides taxation values: basal area, relative share species in volume, average diameter of the trees, medium height of the trees $50 \mathrm{~cm}$ in diameter, significantly depend of the altitude and belonging to particular ecological-vegetation regions in $\mathrm{B} \& \mathrm{H}$.

The result of the analyses is complex model for forest stand volume increment assessment. It was concluded that volume increment of these forest is higher about $1 \mathrm{~m}^{3} /$ ha, now than 50 years ago, when very similar investigation was done in the same forests.
\end{abstract}

Key words: increment, mixed forests of Fir, Spruce and Beech, limestone

\section{INTRODUCTION - Uvod}

Mixed forest of beech, fir and spruce, are the most important part of forest resources in Bosnia and Herzegovina. According results of the second state forest inventory in $\mathrm{B} \& \mathrm{H}$, area of these forests covering about $665300 \mathrm{ha}^{2}$. About 85000 ha

\footnotetext{
${ }^{1}$ Faculty of Forestry University of Sarajevo

${ }^{2}$ Information system of the state forest inventory in B\&H, http://77.74.224.145/
} 
is temporary inaccessible because of mines danger. These forests covering about 371 000 ha land on limestone and dolomite. The most of it (92\%) is in state ownership. It is about $22 \%$ of the total high forest area in the state ownership (1652 $400 \mathrm{ha}$ ) in $\mathrm{B} \& \mathrm{H}$.

Typical uneven aged structure of the tree crowns has $70 \%$ forest stand; group - uneven aged structure has $22 \%$, and two-storey structure about $8 \%$.

Regeneration of these stands is almost exclusively based on natural regeneration, while the artificial introduction of seedlings practiced only sporadically, as a complement to the natural regeneration of stands.

„Tree selection system of management was used in these forests in the past, in which the dominant regeneration of stands natural (MATIC 1977).

PINTARIĆ (1991), defines the tree selection forest as follows: "By this we mean such forest in which in a relatively small area existing trees of all heights and thickness. Trees of different sizes can be mixed individually or in small groups, and can be located next to each other or one below the other. This unevenness is a constant in the selection forest". SCHUTZ $(1975,2001)$ points out that the individualization of production and process of self-care, is the main feature of the tree selection forests stand $^{3}$.

During the $50 \mathrm{~s}, 60 \mathrm{~s}$ and $70 \mathrm{~s}$ of the last century, were carried out extensive research sizes taxation elements of forest stands, as well as their interdependence, of the the economically most important tree species in Bosnia. These studies were first started in the managed forests of beech and fir with spruce (MATIC 1959). Results of these studies are presented in tables (MATIĆ ET ALL. 1963, DRINIĆ ET ALL 1980, 1990) and used for the design of the normal composition of the selection stands (MATIC 1963).

MATIĆ $(1959,1971)$, conducted research sizes taxation elements in managed forests (mixed and pure) of fir, spruce and beech, in Bosnia. On the basis of data collected from 383 temporary sample plots, laid out in these forests, from 1952 to 1958 , the made a comprehensive analysis of the natural process of changing the size of the main taxation elements (measurement characteristics) in the selection forest stands, using the method of multiple regression and correlation analysis. Pure beech and mixed forests of beech and fir with spruce on different soil types and rocks were taken as a unique whole (one population). Regression equations for estimation of the volume increment, diameter increment and volume of fir, spruce and beech in mixed uneven aged forest stands, was the results of analyses. Then follow the research of the dynamics of growth and development of beech and fir forest with spruce and fir and spruce, in the established permanent sample plots (PAVLIČ 1966; DRINIĆ 1972, 1976; BOZALO 1980, 1985).

\footnotetext{
${ }^{3}$ Orig. ,plenterwald“.
} 
In this regard, the first significant researches, to study the growth and development of selection stands, were investigation by BURGER (1950, 1951, and 1952). He presented the results of the volume increment size dependence of other taxation elements sizes in the selection forest stands of beech, fir and spruce.

On the study and the separation of basic and productive forest types in the mixed forests of beech, fir and spruce in Bosnia and Herzegovina, worked ĆIRIĆ, ET ALL (1971). They are, inside these forests in B\&H, isolate and describe 37 basic types of forests within the framework of mixed forests of beech and fir with spruce. Of these, 16 basic types of forest is isolated and described on the limestone and dolomites.

STEFANOVIĆ AT ALL (1983a), were singled out and described several basic types of forests in the forest of fir and spruce, spruce and white pine and spruce forests in the climatogenous belt of the beech and fir forest (with spruce). STEFANOVIĆ ET ALL (1983b) conducted mapping and allocation of ecological-vegetation's rayon in B\&H. $\mathrm{B} \& \mathrm{H}$ territory is divided into provinces, districts and rayons, based on phytogeographic, climate and vegetation components analysis. The province is represented by the broadest category and rayon closest category in this division. Within this zoning, through the descriptions of the individual regions, the ranges of most regional community forests in $\mathrm{B} \& \mathrm{H}$ are described in details.

HASENAUER (2006), points out that in the last few decades there was a significant change in the conditions of growth of forest tree species in Europe. As a contribution to it, cites researches by other authors (KENKA ET ALL 1991, 1993, SPICKER 1996, KARJALAINEN ET ALL 1999). Notes a positive trend of the increasing the productivity of habitats in the southern parts of Northern Europe, Central Europe and some parts of southern Europe.

LOJO (2011), conducted research quality of forests classification to the basic forest management planning units - management classes, exploring, among other things, the process of volume increment changing of mixed stands of beech and fir with spruce on the limestone and dolomites. The results of research, which refers to the size dependence of volume increment of a number of other factors as independent variables, is shown in this paper.

IBRAHIMSPAHIĆ (2013), investigate changes in position of the stand height curves, on the permanent sample plots (plot area 1-2 ha), in the mixed uneven aged forest of fir, beech and spruce on Igman Mountain, based on periodical tree height measurement. She concludes: average tree height, with $50 \mathrm{~cm}$ in breast diameter, could give reliable assessment of the habitat quality for fir, beech or spruce. Height curve has the smallest movement (dislocation up or down) in time for tree diameters around $50 \mathrm{~cm}$.

Knowing the laws change increment, among other things, is a necessary condition for a realistic assessment of normal size and structure of the growing stock in a selection stand, or to create realistic cutting plans. Within this, important question is whether the geographic location within the FB\&H, has a significant impact to size of the increment of the forest. 
Besides the factors, that are measuring characteristics of individual stands, basal area, or the average tree diameter of the stand, the average tree height in the stand as an indicator of habitat quality, the proportion of individual species, the influence of geographical factors: slope, exposure and elevation to the size of volume increment is investigated.

Therefore, the goal of the work is set as follows:

Examine sizes and patterns of the volume increment changes in the forests of beech and fir with spruce on limestone and dolomites in the FB\&H, according to the structural characteristics of growing stocks, orographic characteristics of terrain and affiliation to different ecological- vegetation's rayon in the FB\&H.

\section{THE STUDY SAMPLE - Uzorak}

To solve the goal of this study, we used data collected in uneven aged forest stands, within mixed forests of beech and fir and beech and fir with spruce and fir and spruce forests within. Data was obtained from forest inventories in 11 forest management regions (FMR) in the $\mathrm{F} B \& \mathrm{H}$, which were then selected, analysed and processed at the level of individual stands. Measurements in these areas were carried out during the period 2000 to the 2005 year. From inventory data, the data relating to the above mentioned forests stands, 799 of them, were selected, and compiled into a single database. All selected forest stands are larger than 40 ha, uneven aged structure, and each is uniform per orographic characteristics. That was the criteria for selections

Sample structure by orographic characteristics - Struktura uzorka po orografskim karakteristikama

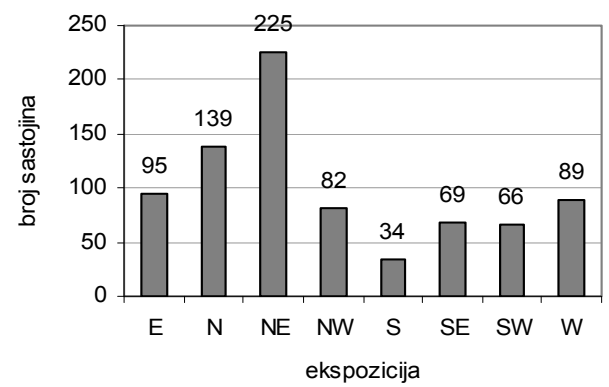

Chart1: Number of stands per exposure Grafikon 1: Broj sastojina po ekspozicijama

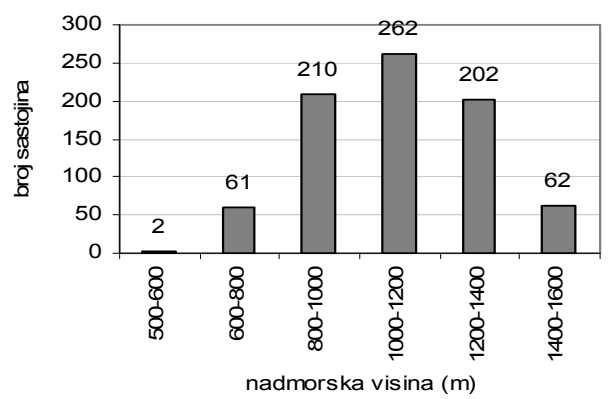

Chart 2: Number of stands per altitude Grafikon 2:Broj sastojina po nadmorskim visinama 
Presence of the exposure in the stands sample is shown in Chart 1. Distribution of stands in the sample, according to altitude is shown in Chart 2 .

The lowest stand is situated at an altitude of $570 \mathrm{~m}$, while the tallest at a height of $1585 \mathrm{~m}$ above the sea level. The average altitude of all the stands in the sample is $1094 \mathrm{~m}$. Altitude of the individual stands is determined by "center of gravity" altitude of polygons representing a stand on the forest vector

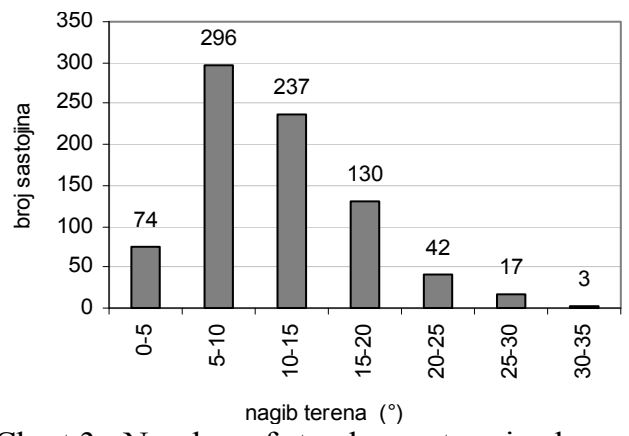

Chart 3: Number of stands per terrain slope Grafikon 3: Broj sastojina prema nagibu terena map.

Considering the method of choice stands in the sample, which was independent of the exposure, slope or elevation, we can say that the pattern of these elements represents well whole collective of the mentioned forest ${ }^{4}$. The distribution of stand by terrain slope, expressed in degrees $\left(^{\circ}\right)$ is shown on Chart 3 .

\section{Sample structure by rayons in FB\&H - Struktura uzorka po rejonima u FBiH}

Given that one of the aims of this work is to investigate the possible influence of climatic factors on the size of the volume increment in considered mixed forest stands, it would be defined a regions, more or less uniform in that.

Table 1: Ecological -vegetation districts and rayons presented in stands sample Tabela 1: Ekološko-vegetacijska područja i rejoni zastupljeni u uzorku

\begin{tabular}{|l|l|l|c|}
\hline \multicolumn{1}{|c|}{ District } & \multicolumn{1}{|c|}{ Rayon } & cod & $\begin{array}{c}\text { Number of } \\
\text { stands }\end{array}$ \\
\hline \hline $\begin{array}{l}\text { West Bosnian limestone - } \\
\text { dolomite district }\end{array}$ & $\begin{array}{l}\text { Ključ-Petrovac without influence of } \\
\text { the Panonian climate }\end{array}$ & B & 353 \\
\cline { 2 - 4 } & $\begin{array}{l}\text { Ključ-Petrovac with influence of the } \\
\text { Panonian climate }\end{array}$ & A & 155 \\
\cline { 2 - 5 } & Glamoč-Kupres rayon & C & 84 \\
\hline Central Bosnian district & Sarajevo -Zenica rayon & D & 4 \\
\hline East Bosnian plateau district & Romanija rayon & E & 47 \\
\hline South-East Bosnian district & Igman-Zelengora rayon & F & 86 \\
\hline $\begin{array}{l}\text { Sub-Mediterranean - } \\
\text { mountainous district. }\end{array}$ & (No isolated rayons). & G & 70 \\
\hline
\end{tabular}

Regionalization of $\mathrm{B} \& \mathrm{H}$, for this purpose can be used, is done in the framework of Ecological - vegetation zoning in Bosnia and Herzegovina (STEFANOVIĆ

\footnotetext{
${ }^{4}$ According data from Second state forest inventory in B\&H
} 
ET ALL 1983). According to the zoning, the largest part of the stands sample, in this work, belongs to the area of internal Dinarides, which stretches from the northeast, from the Plješivica mountain to the Volujak and Maglić mountain, in the southeast part of the B\&H. This area is divided into 7 provinces, of which 4 are represented in the sample. Within them, the sample is represented by 5 rayons. One part of the stands sample belongs to Sub-Mediterranean province, within sub-Mediterranean mountainous district (Table 1).

From the description of the climate rayons, we bring the following:

Ključ-Petrovac district occupies the northwest part of the internal Dinarides area. Within that area the extreme southwest part (rayon A) is under the influence of the Pannonian climate, warmer during summer, where spruce is absent. Spruce participates in mix with fir and beech in the central and south-eastern part (rayon B) of this district, due to more pronounced continental climate. Influence of the continental climate prevailing in the central part, due to the higher altitude during the winter. Stronger influence of Mediterranean climate is during the summer. The ratio of evapotranspiration and precipitation are favourable.

Glamoč - Kupres rayon (C) is extremely mountainous with altitude above $1000 \mathrm{~m}$, in the southern part of the zone, due to the penetration of the Mediterranean climate, the spruce is also absent from forests of beech and fir. Relationship evapotranspiration and precipitation is favourable.

Sarajevo - Zenica rayon (D) occupies the central part of Bosnia and Herzegovina, which also feel strong incursions of the Mediterranean and Pannonian climate, which is why spruce rarely participates in the forests of fir and beech, except at high altitudes, with a smaller proportion of the stand volume.

Romanija rayon (E) occupies the mountainous regions of eastern Bosnia, and stands from the sample are located in the western part. Character of the climate is the mountainous with the influence of the continental climate in the period November May. In the forests of beech and fir, spruce is often significantly presented. The ratio of evapotranspiration and precipitation is favourable.

Igman - Zelengora rayon $(\mathrm{F})$, with the average and distribution of rainfall ( $47 \%$ of rainfall in the growing season) also has a pronounced influence of the Mediterranean climate, but during a winter has a strong influence of the continental climate. Relationship of rainfall and evapotranspiration is favourable.

Sub-Mediterranean district $(G)$ is relatively small and is not divided on the individual rayons. It occupies the south-western part of the Dinarides in B\&H under the strong influence of the Mediterranean climate. Generally above 800 meters above sea level and terrain is very mountainous. Northern border has mainly coincides with watershed between the Adriatic and Black sea basin. Maritime precipitation regime has expressed and the relationship between evapotranspiration and precipitation is favourable. In the higher mountain regions, where the forests of beech and fir presents, spruce is very rare and only occurs at higher elevations, on the border with of the internal Dinarides area and the smaller microclimatic cooler locations. 


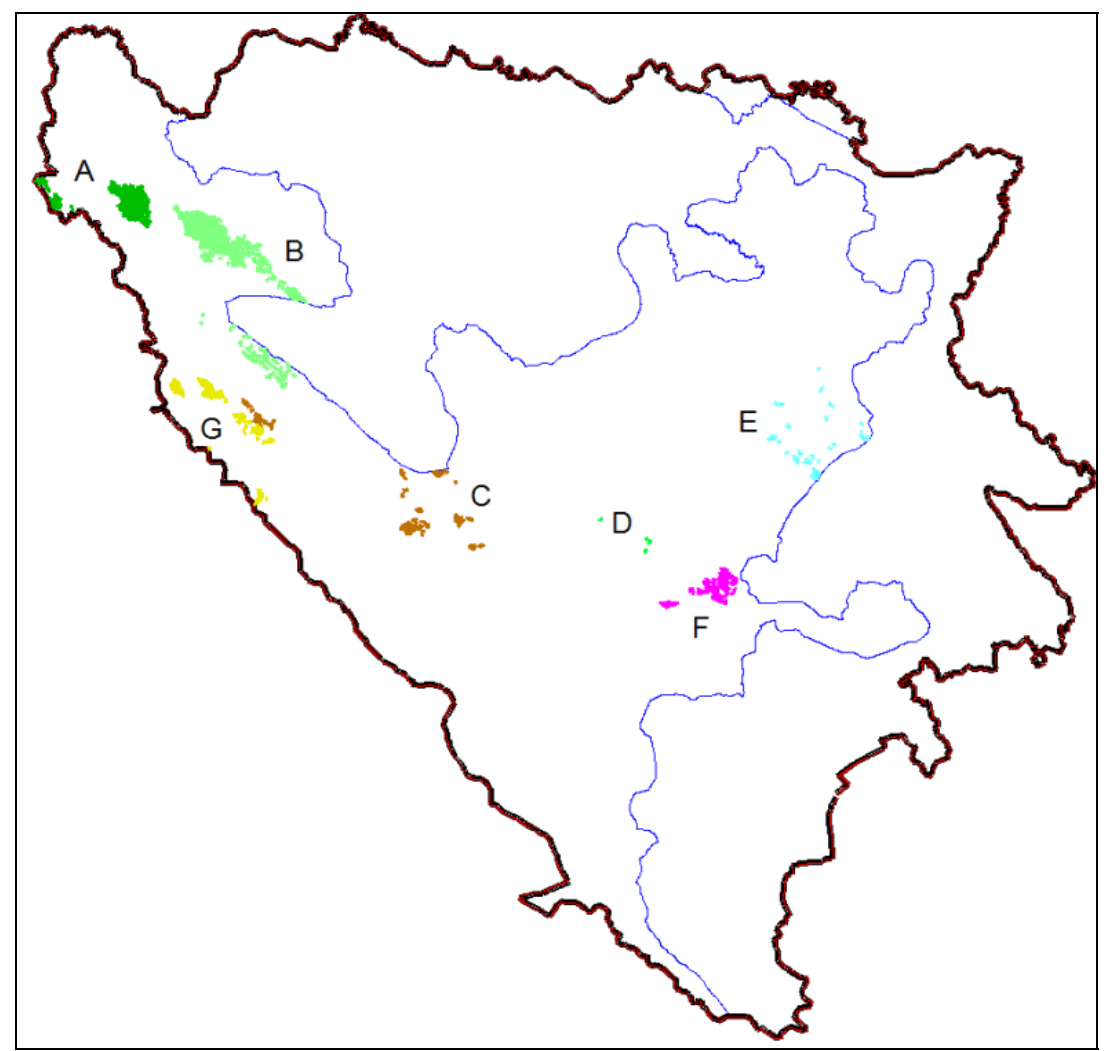

Fig 1: Stand positions from sample in regards to position of the ecological vegetation's rayon in $\mathrm{B} \& \mathrm{H}$

Slika 1: Pripadnost sastojina uzorka pojedinim ekološko-vegetacijskim rejonima u BiH

\section{Sample structure of the stands per habitat quality}

Struktura uzorka po bonitetu staništa

Structure of the sample, according to habitat quality for certain species of trees (determined bay tree height, expressed by absolute measure - average height of trees $50 \mathrm{~cm}$ thick, and by relative quality classes), has presented in Table 2.

The 527 stands which consist of all the three main species of trees together, the average quality habitat, expressed by relative classes and by the average height of trees with a breast diameter of $50 \mathrm{~cm}$, are as follows in Table 3 . Based on the average height of trees with a diameter of $50 \mathrm{~cm}$, of the particular tree species, average height of trees with a diameter of $50 \mathrm{~cm}$ of the all species together (H50-pros), has calculated using the ratio of mixture in stand volume, per tree species as weights.

This measure is used in certain analyses of the structural-production characteristics and interdependencies of the taxation elements of the forest stands, as a 
very good indicator of habitat quality, since the quality measures values of certain tree species "follow" each other in the same forest stand.

Table 2: The structure of the sample by habitat quality for certain species of trees

Tabela 2: Struktura uzoka prema bonitetima staništa za za pojedine vrste drveća

\begin{tabular}{|c|c|c|c|c|c|c|c|}
\hline \multirow[t]{2}{*}{ Spec. } & \multirow{2}{*}{$\begin{array}{l}\text { Num. of } \\
\text { the stands } \\
\text { with spec. }\end{array}$} & \multicolumn{5}{|c|}{$\begin{array}{l}\text { Number of the stands per site quality classes and average } \\
\text { height }(\mathrm{m}) \text { of trees with brest diameter } 50 \mathrm{~cm}(\mathrm{H} 50)\end{array}$} & \multirow{2}{*}{$\begin{array}{c}\text { Average } \\
\text { class }\end{array}$} \\
\hline & & $\begin{array}{c}1 \\
\mathrm{H} 50\end{array}$ & $\begin{array}{c}2 \\
\mathrm{H} 50\end{array}$ & $\begin{array}{c}3 \\
\text { H50 }\end{array}$ & $\begin{array}{c}4 \\
\text { H50 }\end{array}$ & $\begin{array}{c}5 \\
\mathrm{H} 50\end{array}$ & \\
\hline Beech & 763 & $\begin{array}{r}9 \\
32,2 \\
\end{array}$ & $\begin{array}{r}134 \\
29,5\end{array}$ & $\begin{array}{r}411 \\
26,9 \\
\end{array}$ & $\begin{array}{r}175 \\
24,0\end{array}$ & $\begin{array}{r}34 \\
20,8 \\
\end{array}$ & $\begin{array}{r}3,1 \\
26,5\end{array}$ \\
\hline Fir & 783 & $\begin{array}{r}15 \\
32,8\end{array}$ & $\begin{array}{r}166 \\
29,8\end{array}$ & $\begin{array}{r}434 \\
27,0\end{array}$ & $\begin{array}{r}155 \\
24,1\end{array}$ & $\begin{array}{r}13 \\
20,7\end{array}$ & $\begin{array}{r}3,0 \\
27,0\end{array}$ \\
\hline Spru & 575 & $\begin{array}{r}2 \\
35,3\end{array}$ & $\begin{array}{r}61 \\
32,0\end{array}$ & $\begin{array}{r}286 \\
28,5\end{array}$ & $\begin{array}{r}185 \\
25,2\end{array}$ & $\begin{array}{r}20 \\
21,7\end{array}$ & $\begin{array}{r}3,2 \\
27,7\end{array}$ \\
\hline
\end{tabular}

Table 3: Habitat quality for fir, beech and spruce, involving all three species

Tabela 3: Boniteti staništa za jelu, bukvu i smrču u sastojinama u kojima učestvuju sve tri vrste

\begin{tabular}{|l|c|c|c|}
\hline \multicolumn{1}{|c|}{ Tree species } & Beech & Fir & Spruce \\
\hline Habitat quality -relative measure & 3,16 & 2,93 & 3,24 \\
\hline $\begin{array}{l}\text { Average height of trees (m) with } \\
\text { brest diameter } 50 \mathrm{~cm}(\mathrm{H} 50)\end{array}$ & $26,25 \mathrm{~m}$ & $27,09 \mathrm{~m}$ & $27,65 \mathrm{~m}$ \\
\hline
\end{tabular}

Based on the average height of trees with a diameter of $50 \mathrm{~cm}$, of the particular tree species, average height of trees with a diameter of $50 \mathrm{~cm}$ of the all species together (H50-pros), has calculated using the ratio of mixture in stand volume, per tree species as weights.

This measure is used in certain analyses of the structural-production characteristics and interdependencies of the taxation elements of the forest stands, as a very good indicator of habitat quality, since the quality measures values of certain tree species "follow" each other in the same forest stand.

MATIC (1959) has classified the quality of habitat for the growth of fir, spruce and beech in five site quality classes (relative), based on the possible varying height of the trees in a stand, in relation to the brest diameter of the trees. In order to determine the habitat quality, for practical reasons, for these species of trees, based on the position of the tree height curve, he has formed a graphic scheme of the 5 heigt bands for each tree species.

Thees classes are a relative measures of habitat quality. Particular class is determined by continuous variables (height of trees) and can be set equality: class $\mathrm{I}=$ $1.0, \mathrm{II}=2.0$, class $\mathrm{III}=3.0$, etc, but they are still the relative indicators of habitat quality. Variable „H50-pros“ is the absolute measure (indicator) of the habitat quality, and is not bound only for $\mathrm{B} \& \mathrm{H}$ and as such suitable for the analysis of productivity of beech, fir and spruce throughout its area distribution range.

In Table 2, we can see that the stands of the average of the first (I) and fifth (V) quality class a bit and put them together in the sample is less than $1 \%$. Even $63 \%$ 
of stands have moderate habitat conditions (class III) for the growth of these species. In general we can say that the variation of habitat quality for fir, spruce and beech on limestone and dolomite is in 3 relative site quality classess (II, III and IV).

\section{The ratio of tree species in stand volumen by group forest association}

\section{Omjer smjese vrsta drveća po grupama asocijacija šuma}

By the ratio of tree species in the volume of the stand, the structure of the sample is as follows (Table 4):

Tablea 4: The structure of the sample by the average share of tree species in the growing stock of certain types of forests.

Tabela 4: Struktura uzorka prema prosječnom udjelu pojedinih vrsta drveća u zalihi pojedinih vrsta šuma

\begin{tabular}{|l|l|l|l|l|l|l|}
\hline \multirow{2}{*}{\multicolumn{1}{c|}{ Forests }} & Beech & Fir & Spruce & $\begin{array}{l}\text { Noble* } \\
\text { broadleaves }\end{array}$ & All conifers & $\begin{array}{c}\text { All } \\
\text { broadleaves }\end{array}$ \\
\cline { 2 - 8 } & \multicolumn{7}{|c|}{ Share in growing stock (\%) } \\
\hline Beech and Fir with Spruce & 32,4 & 38,8 & 23,9 & 4,1 & 63,1 & 36,9 \\
\hline Fir and Spruce & 1,3 & 42,8 & 51,2 & 1,0 & 97,5 & 2,5 \\
\hline Beech and Fir & 52,6 & 35,9 & 3,2 & 7,6 & 39,1 & 60,9 \\
\hline All forests & 37,6 & 38,2 & 18,2 & 5,1 & 56,8 & 43,2 \\
\hline
\end{tabular}

*Noble broadleaves: ash, maple and elm.

\section{Annual increment of the volume of tree species by types of forests}

Godišnji zapreminski prirast vrsta drveća po vrstama šuma

Table 5: Structure of the sample by annual increment of tree species in certain types of forests.

Tabela 5: Struktura uzoka prema veličini godišnjeg zapreminskog prirasta pojedinih vrsta drveća u pojedinim vrstama šuma

\begin{tabular}{|l|l|l|l|l|l|l|l|}
\hline \multirow{2}{*}{ Forests } & Beech & \multicolumn{7}{|c|}{ Fir } & \multicolumn{7}{|l|}{ Spruce } & $\begin{array}{l}\text { Noble* } \\
\text { broadleaves }\end{array}$ & $\begin{array}{l}\text { All } \\
\text { conifers }\end{array}$ & $\begin{array}{l}\text { All } \\
\text { broadleaves }\end{array}$ & All sp. \\
\cline { 2 - 8 } & \multicolumn{7}{|c|}{ Annual increment of the volumen $\mathrm{m}^{3} /$ ha } \\
\hline $\begin{array}{l}\text { Beech and Fir } \\
\text { with Spruce }\end{array}$ & 2,4 & 3,6 & 2,1 & 0,4 & 5,7 & 2,8 & $\mathbf{8 , 5}$ \\
\hline Fir and Spruce & 0,1 & 4,9 & 3,9 & 0,1 & 9,1 & 0,2 & $\mathbf{9 , 3}$ \\
\hline Beech and Fir & 3,4 & 3,0 & 0,3 & 0,6 & 3,3 & 4,0 & $\mathbf{7 , 3}$ \\
\hline All forests & 2,61 & 3,46 & 1,59 & 0,42 & 5,07 & 3,06 & $\mathbf{8 , 1 4}$ \\
\hline
\end{tabular}




\title{
Growing stock of the tree species by types of the forests
}

Zaliha (zapremina drveta) vrsta drveća po vrstama šuma

Table 6: Structure of the sample by volumen of certain species in certain types of forests

Tabela 6: Struktura uzoka prema veličini zalihe pojedinih vrsta drveća u pojedinim šumama

\begin{tabular}{|c|c|c|c|c|c|c|c|}
\hline \multirow{2}{*}{ Forests } & Beech & Fir & Spruce & $\begin{array}{l}\text { Noble* } \\
\text { broadl. }\end{array}$ & $\begin{array}{l}\text { All } \\
\text { conifers }\end{array}$ & $\begin{array}{l}\text { All } \\
\text { broadl. }\end{array}$ & All sp. \\
\cline { 2 - 9 } & \multicolumn{7}{|c|}{ Volumen - stock $\mathrm{m}^{3} /$ ha } \\
\hline $\begin{array}{c}\text { Beech and Fir with } \\
\text { Spruce }\end{array}$ & 112,5 & 136,7 & 81,8 & 13,6 & 219,8 & 127,3 & $\mathbf{3 4 7 , 0}$ \\
\hline Fir and Spruce & 3,9 & 161,8 & 139,3 & 4,0 & 317,0 & 8,6 & $\mathbf{3 2 5 , 7}$ \\
\hline Beech and Fir & 157,1 & 118,0 & 11,2 & 21,5 & 129,4 & 179,8 & $\mathbf{3 0 9 , 2}$ \\
\hline All forests & 122,3 & 131,7 & 61,6 & 15,7 & 194,8 & 139,2 & $\mathbf{3 3 4 , 0}$ \\
\hline
\end{tabular}

\section{RESULT OF WORK - Rezultati rada}

\begin{abstract}
Size of the annual volume increment (all species combined) in depend of the other taxation elements of the stand - Veličina tekućeg zapreminskog prirasta sastojine (svih vrsta drveća zajedno) u zavisnosti od drugih taksacionih elemenata sastojine
\end{abstract}

Table 7: Variables, code and measuring unit

Tabela 7: Varijable i mjerne jedinice

\begin{tabular}{|l|l|c|}
\hline Variable & $X_{i}$ & $\begin{array}{l}\text { Measurment } \\
\text { unit }\end{array}$ \\
\hline Altitude -above the sea level & VISINA & $\mathrm{m}$ \\
\hline Terrain slope & Nagib & $\circ$ \\
\hline Average height of trees with breast diameter of 50 cm & H50-pros & $\mathrm{m}$ \\
\hline Mean diameter of the trees in the stand, all tree species & DG_sve & $\mathrm{cm}$ \\
\hline Transformed size of the mean diameter & SQ-Dg-sve & \\
\hline Mean diameter of the conifers & Dg-Cet & $\mathrm{cm}$ \\
\hline Share of the Fir in stand volume & OS-Jl & $\%$ \\
\hline Share of the broadleaves in stand volume & OS-Lis & $\%$ \\
\hline Stand basal area & GHA & $\mathrm{m}^{2} / \mathrm{ha}$ \\
\hline Transformed size of stand basal area & BoxCox $(G H A)$ & \\
\hline Land coverage by tree crowns. & STZ & $\%$ \\
\hline Transformed size of the soil coverage & Arcsin_STZ & \\
\hline Annual volume increment & IVHA & $\mathrm{m}^{3} / \mathrm{ha}$ \\
\hline
\end{tabular}

For an explanation of volume increment changes, it is necessary to find a regression model, hich will include all statistically significant factors (variables). In this paper, the goal is not only the best possible estimate of the volume increment in 
some particular cases, but exploring the impact of this size by certain important factors as independent variables, whether categorical or continuous.

To determine the regression model, computer programs "Statistics" 7.0 and "Statgraphic" 5. 0 were used. For better assessment of changes in the size of the annual volume increment (IVHA), selected variables were chosen (Table 7).

Taking into account the criteria of proper procedure of the multiple regressions, some variables used as an independent in the regression equations need to be transformed, by appropriate formula, due to their size structure and type of deviations from normal size distribution. Standardization of all independent variables been imposed as mandatory transformation, in order to avoid problems of variables collinearity (HARTIGAN 1975, PECINA 2006).

Variable altitude (VISINA), slope (Nagib), the average height of the tree with beast diameter $50 \mathrm{~cm}$ (H50-pros), average diameter of the conifer trees (Dg-CET), the share of fir in stock (OS-Jl), the share of broadleaves in stock (OS-Lis), are standardized, that is, there was a transformation of their original size by the following formula:

$$
x_{s t}=\frac{x_{i}-\bar{x}}{s_{x}} ; \ldots
$$

By this transformation, all variables receive an average size 0 and standard deviation 1 (Table 8).

Soil coverage by tree crowns variable (STZ), which did not have even close to a normal distribution of their data, previously transformed by the formula:

$$
\left(\operatorname{Arcsin} \_\mathrm{STZ}\right)=\arcsin (\mathrm{STZ} / 100) \text {; }
$$

This variable is then once again transformed in order to standardize the size, so that the final formula of transformation as follows:

$$
\text { ASIN STZ }=\frac{\arcsin ^{S T Z} / 100-1,117}{0,26}
$$

Variable GHA - stand basal area, had approximately a normal distribution size, but not nearly linear effect on the size of the volume increment (IVHA). Through BoxCox transformation the size of the exponent " $\lambda$ " of 0.329 , was calculated, using all stands from the sample, setting the regression relationship: GHA $=\mathrm{f}$ (IVHA). Thus obtained the recommended transformation of GHA:

$\operatorname{Box} \operatorname{Cox}(G H A)=1+\frac{G H A^{0,329}-1}{0,329 \cdot 30,0227^{-0,671}} ; \quad$ Standardization of these quantities is then made:

$$
G H A_{-} T S=\frac{\operatorname{Box} \operatorname{Cox}(\mathrm{GHA})_{i}-63,03}{7,29} .
$$


Variable Mean diameter of the stand of all species (DG_sve) is only one standardized (DG_sve_st). Then DG-sve variable is transformed again, according to the formula $x_{T}=\sqrt{x}$, and then standardized (1). So, another independent variable SQ_Dg_st is obtained.

Table 8 shows the original and the transformed and standardized variables $\left(X_{s t i}\right)$.

Table 8: Average size and variability of the original and (transformed) standardized sizes of variables for 799 stands from sample

Tabela 8: Prosječne veličine i mjere varijabiliteta za originalne i (transformisane i) standardizovane veličine varijabli za 799 sastojina uzorka

\begin{tabular}{|c|c|c|c|c|c|c|c|}
\hline$x_{i}$ & $\bar{X}_{i}$ & Min. & Max. & $S_{x}$ & $x_{s t i}$ & $\bar{x}_{s t i}$ & $S_{x s t}$ \\
\hline VISINA & 1094 & 570 & 1585 & 208,4 & $\mathrm{Nd}$ Vis st & 0,00 & 1,000 \\
\hline Nagib & 11,4 & 0 & 31,8 & 5,57 & Nagib_st & 0,00 & 1,000 \\
\hline H50-pros & 27,15 & 21,27 & 33,11 & 2,08 & $\mathrm{H} 50$ pr_st & 0,00 & 1,000 \\
\hline DG_sve & 23,52 & 12,7 & 39,05 & 4,31 & DG_sve_st & 0,00 & 1,000 \\
\hline SQ-Dg-sve & 4,83 & 3,563 & 6,249 & 0,440 & SQ Dg_st & 0,00 & 1,000 \\
\hline Dg-Cet & 26,44 & 0 & 65,1 & 7,31 & Dg_Č_st & 0,00 & 1,000 \\
\hline OS-JI & 38,21 & 0 & 99,3 & 20,43 & OS_Jl_st & 0,00 & 1,000 \\
\hline OS-Lis & 43,18 & 0 & 100 & 26,12 & OS_L_st & 0,00 & 1,000 \\
\hline GHA & 30,9 & 12,05 & 57,56 & 7,31 & \multirow{2}{*}{ GHA_TS } & \multirow{2}{*}{0,000} & \multirow{2}{*}{1,000} \\
\hline BoxCox (GHA) & 63,03 & 38,96 & 84,62 & 7,29 & & & \\
\hline STZ & 86,95 & 32,6 & 100 & 12,34 & & & \\
\hline Arcsin_STZ & 1,117 & 0,332 & 1,571 & 0,260 & ASIN_STZ & 0,000 & 1,000 \\
\hline IVHA & 8,14 & 2,59 & 17,39 & 2,58 & BoxCox(IVHA) & 15,74 & 2,5413 \\
\hline
\end{tabular}

Optimal set of influential variables and their interactions-products is obtained, using GRM (generalized regression models) module in "Statistic 7.0 "Forward stepwise" selection procedure of the most influential variables, and inclusion of the transformed variables size of individual stands in the sample was used (Table 9, value "p" <0.05). Their influence on the dependent variable IVHA was statistically significant, and the selected variables and their interactions were not collinear with each other (Table 11, inflation factor VIF $<5)(P E C I N A$ 2006). The significance of the influence of individual variables and their interactions is shown in Table 9 (F ratio of the variances).

The variable slope "Nagib-st" had no statistically significant effect on the size of the volume increment (IVHA), as a single variable, or, in interaction with other variables. In the final step of determining the regression equation, the independent variable - volume increment (IVHA) is also transformed in order to complete homogenization of variance and normalization of residuals. 
Table 9: Results of regression (GRM) - ANOVA table - the importance of the influence of various factors on the size of the volume increment (IVHA)

Tabela 9: Rezultat regresije (GRM) - Anova tabela - značaj uticaja pojedinih faktora na veličinu zapreminskog prirasta sastojine (IVHA)

\begin{tabular}{|c|c|c|c|c|c|}
\hline Factors & Variance & $\begin{array}{l}\text { Deg. of } \\
\text { freedom }\end{array}$ & Mean & $\mathrm{F}$ & $\mathrm{p}$ \\
\hline Nd_Vis_st & 391,636 & 1 & 391,636 & 279,82 & 0,0000 \\
\hline Dg_Č_st & 52,4701 & 1 & 52,4701 & 37,49 & 0,0000 \\
\hline H50-pr-st & 1023,79 & 1 & 1023,79 & 731,49 & 0,0000 \\
\hline ASIN_STZ & 374,09 & 1 & 374,09 & 267,29 & 0,0000 \\
\hline OS_L_st & 993,834 & 1 & 993,834 & 710,09 & 0,0000 \\
\hline GHA_TS & 1089,68 & 1 & 1089,68 & 778,57 & 0,0000 \\
\hline Nd_Vis_st*Dg_sve_st & 5,11158 & 1 & 5,11158 & 3,65 & 0,0560 \\
\hline Nd_Vis_st*H50_pr_st & 26,7389 & 1 & 26,7389 & 19,10 & 0,0000 \\
\hline Dg_sve_st*OS_L_st & 1,33433 & 1 & 1,33433 & 0,95 & 0,3289 \\
\hline Dg_Č_st*OS_L_st & 38,1162 & 1 & 38,1162 & 27,23 & 0,0000 \\
\hline ASIN_STZ*GHA_TS & 10,6067 & 1 & 10,6067 & 7,58 & 0,0059 \\
\hline ASIN_STZ*OS_J_st*OS_L_st & 20,2982 & 1 & 20,2982 & 14,50 & 0,0001 \\
\hline $\begin{array}{l}\text { Nd_Vis_st*H50_pr_st*GHA_ } \\
\text { TS }\end{array}$ & 10,027 & 1 & 10,027 & 7,16 & 0,0074 \\
\hline $\begin{array}{l}\text { Nd_Vis_st*ASIN_STZ*OS_Jl } \\
\text { st*SQ_Dg_st }\end{array}$ & 18,7568 & 1 & 18,7568 & 13,40 & 0,0003 \\
\hline Model & 4056,49 & 14 & & & \\
\hline
\end{tabular}

BoxCox transformation was applied with " $\lambda "=0.07$ :

$$
\operatorname{BoxCox}(I V H A)=1+\frac{I V H A^{0,07}-1}{0,07 \cdot 7,72342^{-0,93}}
$$

Table 10 shows the variance explained part of the variation of the dependent variable (Model) and the unexplained part of the variation (Residual) and the ratio of these variances $F$.

Degree explanations expressed through determination coefficient $\mathrm{R}^{2}=0.787$, $\mathrm{R}^{2}$ (corrected) $=0.783$, while the standard error of the estimate $=1.183 \mathrm{~m}^{3} / \mathrm{ha}$.

Table 11 shows the calculated values of parameters in equation with indicators of their importance. Since the calculated size of the inflation factor VIF $<5$, for each parameter, and $r_{i}^{2}<R^{2}$, there is no problem of multi-collinearity between individual variables and their interactions. 
Table 10: Results of regression (GRM) ANOVA table - the importance of the influence of independent variables on the IVHA - Model 1.

Tabela 10: Rezultat regresije (GRM) Anova tabela - značaj uticaja svih nezavisnih varijabli na veličinu IVHA - Model 1

\begin{tabular}{|c|l|l|l|l|c|}
\hline $\begin{array}{c}\text { Source of } \\
\text { variability }\end{array}$ & $\begin{array}{c}\text { Sum of } \\
\text { squares }\end{array}$ & $\begin{array}{c}\text { Deg. of } \\
\text { freedom }\end{array}$ & Variance & F- ratio & $\begin{array}{c}\text { "P" } \\
\text { probability }\end{array}$ \\
\hline Model & 4056,49 & 14 & 289,749 & 207,02 & 0,0000 \\
\hline Residual & 1097,28 & 784 & 1,39959 & & \\
\hline Total (corrected) & 5153,77 & 798 & & & \\
\hline
\end{tabular}

Table 11: Results of regression (GRM), size and importance of the parameters of the independent variables - Model 1.

Tabela 11: Rezultat regresije (GRM) veličine i značaj parametara uz nezavisne varijableModel 1

\begin{tabular}{|l|c|c|c|c|c|c|}
\hline \multicolumn{1}{|c|}{ Variable } & Parameter & $\begin{array}{c}\text { Standard } \\
\text { error }\end{array}$ & $\mathrm{t}$ - test & $\begin{array}{c}\text { "p“ } \\
\text { prob. }\end{array}$ & $\mathrm{r}^{2}$ & VIF \\
\hline Konstanta & 15,93566 & 0,050008 & 318,6609 & 0,000000 & & \\
\hline Nd_Vis_st & $-0,62217$ & 0,051399 & $-12,1047$ & 0,000000 & 0,34 & 1,506290 \\
\hline Dg_Č_st & $-0,44120$ & 0,052951 & $-8,3321$ & 0,000000 & 0,38 & 1,610283 \\
\hline H50-pr-st & 0,43012 & 0,049613 & 8,6694 & 0,000000 & 0,29 & 1,403448 \\
\hline ASIN_STZ & 0,33786 & 0,061283 & 5,5131 & 0,000000 & 0,53 & 2,141345 \\
\hline OS_L_st & $-0,84630$ & 0,051489 & $-16,4364$ & 0,000000 & 0,34 & 1,511590 \\
\hline GHA_TS & 1,53520 & 0,058543 & 26,2234 & 0,000000 & 0,49 & 1,954134 \\
\hline Nd_Vis_st*Dg_sve_st & $-0,10348$ & 0,043583 & $-2,3742$ & 0,017825 & 0,12 & 1,131647 \\
\hline Nd_Vis_st*H50_pr_st & 0,20607 & 0,043644 & 4,7215 & 0,000003 & 0,15 & 1,174432 \\
\hline Dg_sve_st*OS_L_st & $-0,21482$ & 0,053249 & $-4,0342$ & 0,000060 & 0,42 & 1,712271 \\
\hline Dg_C__st*OS_L_st & 0,22830 & 0,047383 & 4,8182 & 0,000002 & 0,54 & 2,174214 \\
\hline ASIN_STZ*GHA_TS & $-0,15300$ & 0,041551 & $-3,6823$ & 0,000247 & 0,15 & 1,175951 \\
\hline ASIN_STZ*OS_J_st*OS_L_st & 0,17463 & 0,040262 & 4,3374 & 0,000016 & 0,31 & 1,453592 \\
\hline Nd_Vis_st*H50_pr_st*GHA_TS & 0,09416 & 0,040364 & 2,3328 & 0,019911 & 0,36 & 1,558739 \\
\hline Nd_Vis_st*ASIN_STZ*OS_Jl_st*SQ_Dg_st & 0,13082 & 0,035735 & 3,6608 & 0,000268 & 0,16 & 1,190956 \\
\hline
\end{tabular}

Finally, established mathematical model of regressions equation (model 1) is:

$\operatorname{BoxCox}(\mathrm{IVHA})=15,9361-0,62217 * \mathrm{Nd}$-Vis_st $-0,442799 * \mathrm{Dg}$ C__st + $0,430116 *$ H50_pr_st $+0,337864 *$ ASIN_STZ $-0,846538 *$ OS_L_st + $1,5352 *$ GHA_TS $-0,103478 * \mathrm{Nd}$ Vis_st*Dg_sve_st + $0,206068 * \mathrm{Nd}_{-}^{-}$Vis_st*H50_pr_st $-0,21482 * \overline{D g} \_$sve_st*OS_L_st +

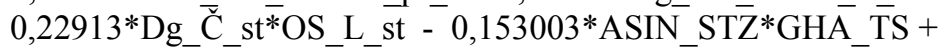
$0,17463 * A S I N \_S T Z * O S$ OS_Jl_st*OS_L_st +

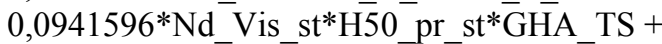
$0,13082 * \mathrm{Nd} \_\mathrm{Vi} \_\mathrm{st} * \mathrm{ASIN} \_\mathrm{STZ} * \mathrm{OS} \_J 1$ _st $* S Q \_D g \_s t$.

Where is: $\operatorname{Box} \operatorname{Cox}(I V H A)=1+\frac{I V H A^{0,07}-1}{0,07 \cdot 7,72342^{-0,93}}$ 
Chart 4 shows the quality of the regression by schedule deviations (residuals) from the estimated actual size of the dependent variable volume increment (IVHA). From this description, and the next, in Chart 5, it can be seen that the schedule of the residual is random throughout the domain of the size IVHA, i.e., there is no systematic deviation of the residuals around estimated value, in any part of the domain changes variable IVHA, and that the variance of the residuals, according to the Chart, 5, is homogeneous as a result of optimization of the regression, using BoxCox transformation of the dependent variable.

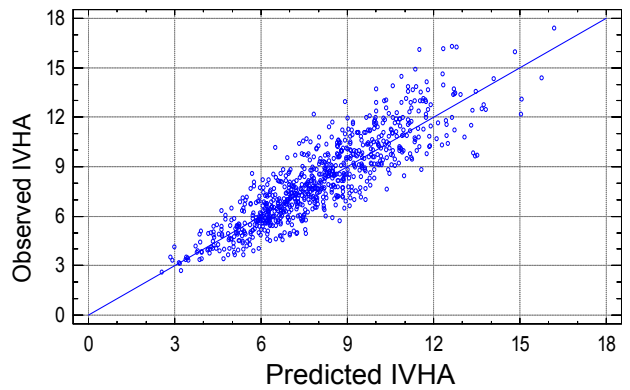

Chart 4: Deviation of actual from estimated values of the volume increment (Model 1)

Grafikon 4: Odstupanje stvarnih od procijenjenih veličina zapreminskog prirasta sastojine (Model 1)

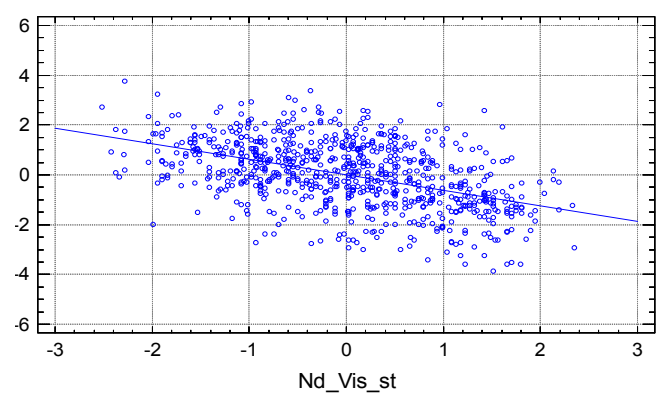

Chart 6: The effect of altitude (Nd-Vis-st) on the size of volume increment (IVHA) shown with residuals

Grafikon 6: Uticaj nadmorske visine (Nd-Vis-st) na veličinu zapreminskog prirasta sastojine (IVHA) sa prikazanim rezidualima (Model 1)

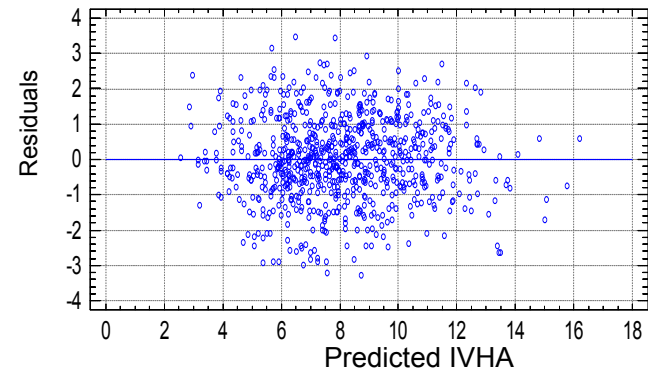

Chart 5: Distribution of residuals about the estimated values of the volume increment (Model 1)

Grafikon 5: Raspored reziduala oko procijenjenih veličina zapreminskog prirasta sastojine (Model 1)

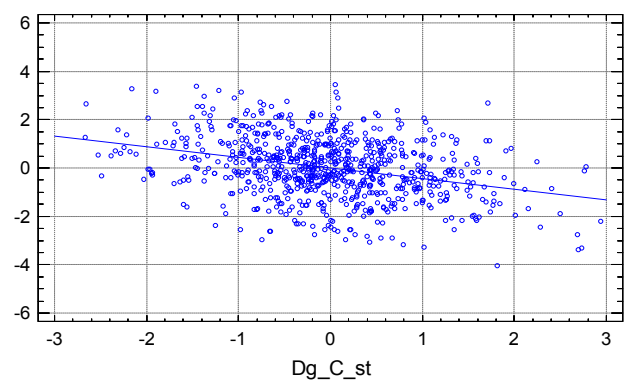

Chart 7: Effect of mean diameter of conifers in the stand Dg_ $\check{C}_{-}$st on the size of the volume increment (IVHA) shown with residuals

Grafikon 7: Uticaj srednjeg prečnika četinara u sastojini (Dg_C_st) na veličinu zapreminskog prirasta sastojine (IVHA) sa prikazanim rezidualima (Model 1) 
Charts 6 to 11, shows the individual effects of the independent variables in their transformed size, on the dependent variable - volume increment (IVHA), with average size and the influence of other independent variables in the equation model 1 , and the average individual interaction effects of independent variables. From the distribution of residuals cannot be seen that there is a systematic deviation in any part of the domain of independent variables, which indicates the quality of the regression equation and the specified parameters.

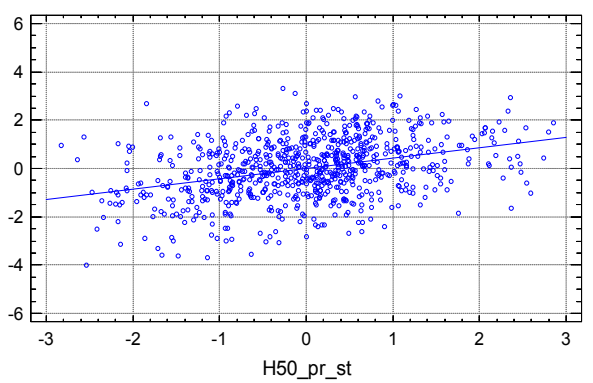

Chart 8: The influence of the average height of trees with diameter $50 \mathrm{~cm}\left(\mathrm{H} 50 \_\right.$pr_st $)$ on the size of volume increment (IVHA) shown with residuals

Grafikon 8:Uticaj prosječne visine stabala prečnika $50 \mathrm{~cm}$ (H50_pr_st) na veličinu zapre minskog prirasta sastojine (IVHA) sa prikazanim rezidualima (Model 1)

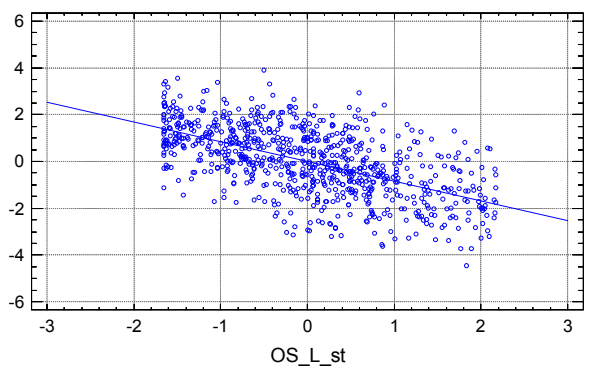

Chart 10: Influence of broadleaves share in the stock stands(OS_L_st) on the size of volume increment (IVHA) shown with residuals

Grafikon 10: Uticaj udjela lišćara u zalihi sastojine ( $\left.O S \_L \_s t\right)$ na veličinu zapreminskog prirasta sastojine (IVHA) sa prikazanim rezidualima (Model 1)

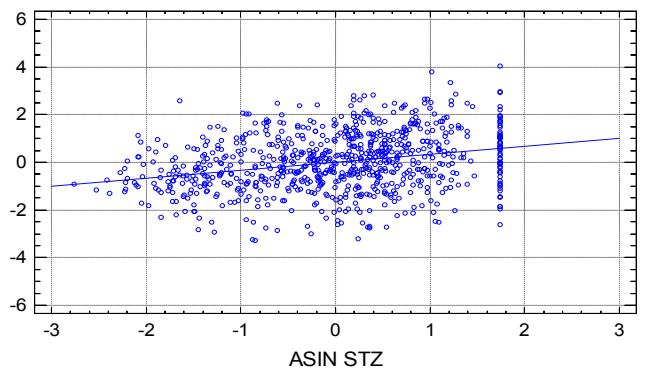

Chart 9: The effect of land cover of the trees (ASIN STZ) on the size of volume increment (IVHA) shown with residuals

Grafikon 9:Uticaj prekrivenosti zemljišta krošnjama stabala (ASIN STZ) na veličinu zapreminskog prirasta sastojine (IVHA) sa prikazanim rezidualima (Model 1)

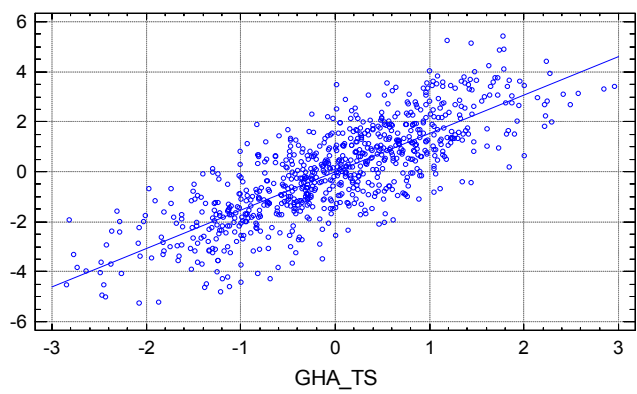

Chart 11: Influence of stand basal area (GHA_TS) on the size of volume increment (IVHA) shown with residuals

Grafikon 11:Uticaj temeljnice sastojine (GHA TS) na veličinu zapreminskog prirasta sastojine (IVHA) sa prikazanim rezidualima (Model 1) 
From charts can be seen the character of the influence of individual variables, i.e., does the size of the dependent variable IVHA increases or decreases with increasing the size of some of the independent variables. To display the real - absolute impact of an individual variables, or explanations of impact character on the dependent variable, it should construct a curve with the original sizes of the dependent and independent variables. It's done for impact of the stand basal area (GHA) variable and shown on Chart 12.

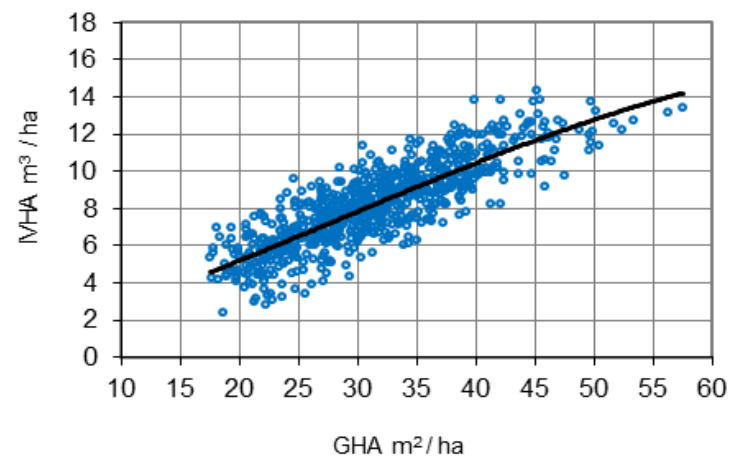

Chart 12: Impact of stand basal area (GHA) on the size of annual volume increment (IVHA) shown with residuals around fitted value

Grafikon 12: Uticaj temeljnice sastojine (GHA) na veličinu zapreminskog prirasta sastojine (IVHA) sa prikazanim rezidualima oko krive procjenjenih veličina

Size of the annual volume increment depending on the location in the FBiH and the exposure of the stand - Veličina godišnjeg zapreminskog prirasta sastojine $u$ zavisnosti o ekološko-vegeticskom rejomu u FBiH i ekspozicije sastojine

When the most influential set of continuous independent variables and their interactions, the size of the volume increment (IVHA) was chosen, trough procedure Forward-Stepwise, categorical variables are then included as independent in the regression model (2):

- Ecological vegetation rayon (EV_R), and

- Exposure of the stand (Exp), by the 8 possible (N - Northern exposure, NE Northeast, E - East, SE - South East, S - South, North - South East, W - West, NW - North-western).

These categorical variables in the regression model can be included together with continuous in one regression model, in the GLM (generalised linear models) module computer program "Statgraphic". The same transformation of the dependent variable (IVHA), as in model 1 was kept. (Applied BoxCox transformation: $\lambda=0.07$ ). The result of the regression is shown in Table 12, 13, and 14. 
Table 12: Results of regression (GLM) (ANOVA table) - the importance of the influence of independent variables on the volume increment (Model 2).

Tabela 12: Rezultat regresije (GLM) (Anova tabela) - značaj uticaja svih nezavisnih varijabli na veličinu zapreminskog prirasta sastojine (Model 2)

\begin{tabular}{|c|l|l|l|l|l|}
\hline Source of variability & $\begin{array}{c}\text { Sum of } \\
\text { squares }\end{array}$ & $\begin{array}{c}\text { Deg. of } \\
\text { freedom }\end{array}$ & Variance & F- ratio & $\begin{array}{c}\text { "P" } \\
\text { probability }\end{array}$ \\
\hline Model & 4108,92 & 27 & 152,182 & 112,30 & 0,0000 \\
\hline Residual & 1044,85 & 771 & 1,35519 & & \\
\hline Total (corrected) & 5153,77 & 798 & & & \\
\hline
\end{tabular}

Increasing the number of independent variables (Model 2) slightly increases the degree of explanation IVHA, for about 1\%. Degree explanations expressed through determination coefficient $\mathrm{R}^{2}=0.79, \mathrm{R}^{2}$ (corrected) $=0.79$, while the standard error of the estimate $=1.16 \mathrm{~m}^{3} /$ ha. Exposure showed no statistically significant effect on the size of the volume increment (Chart 14), while the influence of stands belonging to different eco- vegetation's rayon of in FB\&H, significant (Table 13, the value "F" and "p" for variable EV_R and EKSP).

Table 13: Results of regression (GLM-ANOVA table) - the importance of the influence of various factors on the size of the volume increment (Model regression equations 2).

Tabela 13: Rezultat regresije (GLM) (Anova tabela) - značaj uticaja pojedinih faktora na veličinu zapreminskog prirasta sastojine (Model regresione jednačine 2)

\begin{tabular}{|l|l|l|l|l|l|}
\hline \multicolumn{1}{|c|}{ Factors } & $\begin{array}{c}\text { Sum of } \\
\text { squares }\end{array}$ & $\begin{array}{c}\text { Deg. of } \\
\text { freedom }\end{array}$ & Variance & F- ratio & "P” prob. \\
\hline EV_R & 39,1644 & 6 & 6,5274 & 4,82 & 0,0001 \\
\hline EKSP & 12,0193 & 7 & 1,71705 & 1,27 & $0,2638^{*}$ \\
\hline Nd_Vis_st & 85,749 & 1 & 85,749 & 63,27 & 0,0000 \\
\hline Dg_Č_st & 65,7505 & 1 & 65,7505 & 48,52 & 0,0000 \\
\hline H50-pr-st & 83,0697 & 1 & 83,0697 & 61,30 & 0,0000 \\
\hline ASIN_STZ & 40,4012 & 1 & 40,4012 & 29,81 & 0,0000 \\
\hline OS_L_st & 322,625 & 1 & 322,625 & 238,07 & 0,0000 \\
\hline GHA_TS & 736,519 & 1 & 736,519 & 543,48 & 0,0000 \\
\hline Nd_Vis_st*Dg_sve_st & 5,58096 & 1 & 5,58096 & 4,12 & 0,0424 \\
\hline Nd_Vis_st*H50_pr_st & 21,7216 & 1 & 21,7216 & 16,03 & 0,0001 \\
\hline Dg_sve_st*OS_L_st & 18,0801 & 1 & 18,0801 & 13,34 & 0,0003 \\
\hline Dg_Č__**OS_L_st & 19,6697 & 1 & 19,6697 & 14,51 & 0,0001 \\
\hline ASIN_STZ*GHA_TS & 16,2502 & 1 & 16,2502 & 11,99 & 0,0005 \\
\hline ASIN_STZ*OS_J_st*OS_L_st & 22,0457 & 1 & 22,0457 & 16,27 & 0,0001 \\
\hline Nd_Vis_st*H50_pr_st*GHA_TS & 4,50188 & 1 & 4,50188 & 3,32 & $0,0684^{*}$ \\
\hline Nd_Vis_st*ASIN_STZ*OS_J1st*SQ_Dg_st & 16,237 & 1 & 16,237 & 11,98 & 0,0005 \\
\hline Rezidual & 1044,85 & 771 & 1,35519 & & \\
\hline Total(corrected) & 5153,77 & 798 & & & \\
\hline
\end{tabular}

*Is not significant

Other independent variables and their interactions still have a statistically significant effect on the dependent variable, except for one interaction $(\mathrm{Nd}$ _Vis_st * H50_pr_st * GHA_TS), whose size p slightly exceeds the level of significance of 
0.05 . The differences in the sizes of the calculated size of volume increment by some of the regions are statistically significant, but such differences do not exist between all regions (Table 13). It is obvious from the Chart 13.

Table 14: LSD Fisher's test, homogeneous group of stand-ecological vegetation regions, the probability of $95 \%$ by the size of volume increment (IVHA)

Tabela 14: LSD Fisher test; homogene grupe sastojina- ekološko-vegetacijskih rejona, pri vjerovatnoći od 95\% prema veličini zapreminskog prirasta sastojine (IVHA)

\begin{tabular}{|c|c|c|c|l|l|}
\hline EV_R & $\begin{array}{c}\text { Number of } \\
\text { stands }\end{array}$ & $\begin{array}{c}\text { IVHA } \\
\left(\mathrm{m}^{3} / \mathrm{ha}\right)\end{array}$ & \multicolumn{3}{|c|}{$\begin{array}{c}\text { Homogenous } \\
\text { groups }\end{array}$} \\
\hline $\mathrm{D}$ & 4 & 6,79 & $\mathrm{x}$ & & \\
\hline $\mathrm{C}$ & 84 & 7,19 & $\mathrm{x}$ & & \\
\hline $\mathrm{G}$ & 70 & 7,47 & $\mathrm{x}$ & $\mathrm{x}$ & \\
\hline $\mathrm{A}$ & 155 & 7,80 & & $\mathrm{x}$ & $\mathrm{x}$ \\
\hline $\mathrm{F}$ & 86 & 7,80 & & $\mathrm{x}$ & $\mathrm{x}$ \\
\hline $\mathrm{B}$ & 353 & 7,97 & & & $\mathrm{x}$ \\
\hline $\mathrm{E}$ & 47 & 8,12 & & & $\mathrm{x}$ \\
\hline
\end{tabular}

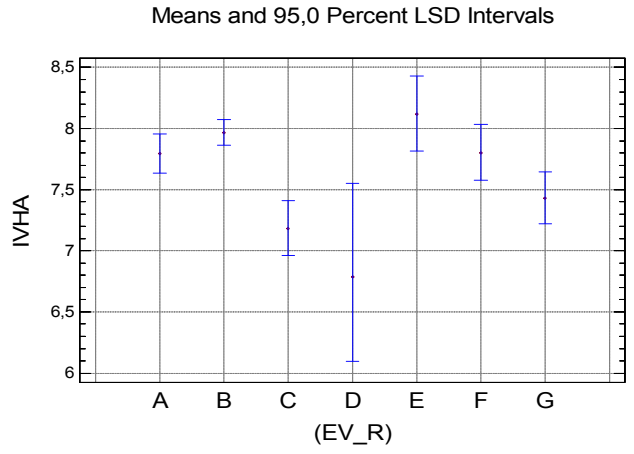

Chart 13: Fisher LSD tests. Influence of the ecological vegetation's rayon on the size of the volume increment (IVHA)

Grafikon 13: LSD Fisher test. Uticaj pripadnosti sastojine ekološko-vegetacijskom rejonu na veličinu zapreminskog prirasta sastojine (IVHA),

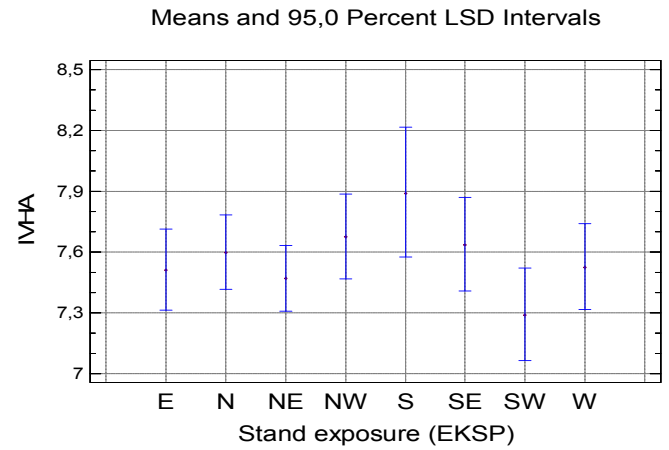

Chart 14: Fisher LSD tests. Influence of the exposure of the stand on the size of the volume increment (IVHA) - is not significant

Grafikon 14: LSD Fisher test. Uticaj ekspozicije sastojine na veličinu zapreminskog prirasta sastojine (IVHA)

In Figure 2, the same color rounded stands within individual regions, among which there is no difference in size of volume increment, (with the same sizes of the other independent variables in the equation model 2).

If we analyse the schedule mutually similar EV_R in Figure 2 (or table 14), it is easy to conclude that grouping those rayons, which are similar in character of the climate. Kljuc -Petrovac (B) and Romanija (E) with a typical continental mountain climate, in which the volume of increment is, in average, higher than the increment of other rayons. Glamoč - Kupres rayon is characterized by its extremely cold and long 
winters and incursions of the Mediterranean climate in summer. Spruce is on the edge of its own area. The conditions for the growth of stands, according to the results of this analysis, are slightly worse in this rayon comparing to rayons with a continental mountain climate. In other rayons, impact of continental mountain climate is mixing with occasional impacts of the Pannonian - summer drought, or Mediterranean climate. In terms of the conditions for the growth of stands make the transition between the previous two groups of the rayons.
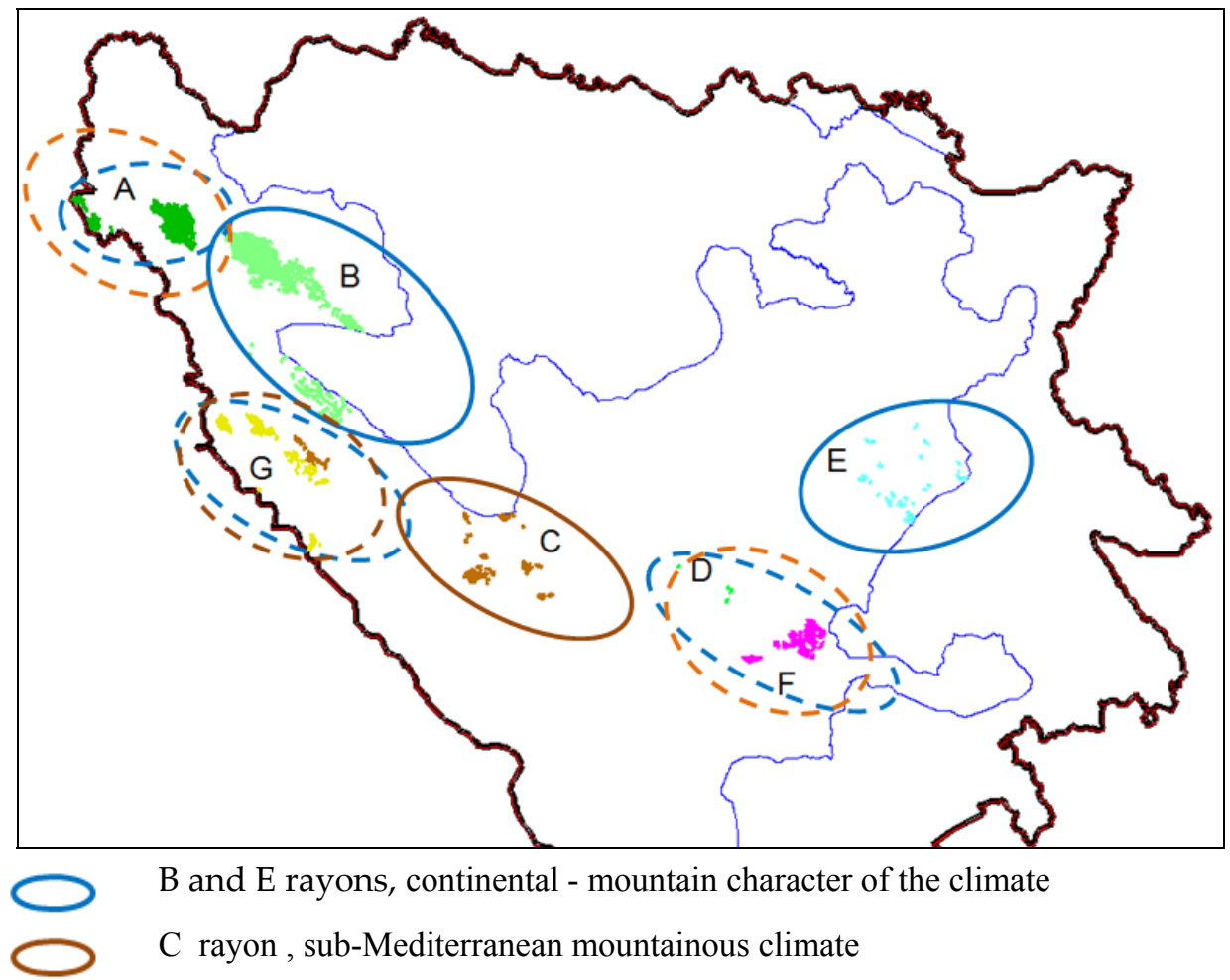

$\mathrm{B}$ and $\mathrm{E}$ rayons, continental - mountain character of the climate

C rayon, sub-Mediterranean mountainous climate

\& $\begin{aligned} & \mathrm{A}, \mathrm{F}, \text { and } \mathrm{G} \text { rayons, zones of incursions Mediterranean climate in summer and } \\ & \text { mountainous climate in winter }\end{aligned}$

Figure 2: Ecological- vegetation rayons similar in increment size

Slika 2: Ekološko-vegetacijski rejoni slični po veličini zapreminskog prirasta

This result, due to the geographical distribution mutually similar regions per volume of the annual increment (IVHA) is a logical. The real and detailed reasons for the observed differences in the size of the increment are not necessary to find, into this work. It is enough to say that there are significant differences in the volume of timber of the same forest stands, in certain rayons of the Federation of Bosnia and Herzegovina. 


\section{DISCUSSION AND CONCLUSION - Diskusija i zaključci}

The goal of the analysis in this work is focused on exploring the impact of ecological vegetation rayonss (EV_R), exposure of the stand (EXP), and the altitude, on the size of volume increment (IVHA) within mixed stands of beech, fir and spruce. In order to investigate the influence of these factors, previously it was necessary to eliminate the effects of other factors - structural characteristics of the stand, which was done in the first step in forming a regression model 1 , which includes all significant continuous measuring variables. In the second step, categorical variables are included (in model 2): exposure of the stands and ecological-vegetation rayons in Bosnia and Herzegovina.

It has been shown that exposure of the stand had no significant effect on the size of the volume increment, while ecological-vegetation rayons had important and statistically significant effect on the size of the volume increment. In Figure 2, homogenous groups of the rayons, (EV_R) which do not differ in the size of the volume increment, are the color-coded, It could be seen that there is a logical arrangement in the space, and the differences in the size of the increment, between individual rayons can be explained by the character of their climate.

Also, effect of altitude is significant. With increasing altitude, size of the annual increment reduces. Increment is reducing about $1 \mathrm{~m}^{3} /$ ha in the range of height distribution, 600 to $1400 \mathrm{~m}$ above the sea level, with the same other sizes of factors affecting the change in increment.

How is the sample for analysis in this paper is representative, showing comparative data from mixed forests of beech, fir and spruce, of this sample and data gained from Second state forest inventory in B\&H, conducted in the period 2006-2009 in table 15 .

Table 15 shows the average data of the annual volume increment, from the sample of this study (sample), and the average size of the increment of selected plots data from Second state forest inventory in Bosnia and Herzegovina (SFI_B\&H), for each type of forest. The differences in the estimated increment volume are small and do not exceed the statistical error of the increment volume estimates in SFI_BiH.

MATIC (1959) conducted a similar study in the framework of these forests. His sample had included even the stand on silicate soils-rocks in B\&H. He also conducted similar researches about character of the volume increment changes of these forests. 
Table 15: Comparison of data of the volume increment, from the sample of this study and data from Second state forest inventory in Bosnia and Herzegovina (SFI_B\&H), for certain types of forest in the $\mathrm{B} \& \mathrm{H}$.

Tabela 15: Poređenje veličina zapreminskog prirasta, iz uzorka ovog rada (UZORAK) $i$ podataka druge državne inventure šuma u Bosni i Hercegovini (SFI_BiH), za pojedine vrste šuma u FBiH

\begin{tabular}{|c|c|c|c|c|}
\hline \multirow{2}{*}{ Forests } & \multirow[b]{2}{*}{$\begin{array}{c}\text { Source of the } \\
\text { data }\end{array}$} & \multicolumn{3}{|c|}{ Annual volume increment $\mathrm{m}^{3} / \mathrm{ha}$} \\
\hline & & All conifers & All broadleaves & All species \\
\hline \multirow{2}{*}{$\begin{array}{l}\text { Beech, Fir with } \\
\text { Spruce }\end{array}$} & Sample & 5,7 & 2,8 & 8,5 \\
\hline & SFI_B\&H & 5,7 & 3,0 & 8,7 \\
\hline \multirow{2}{*}{ Fir and Spruce } & Sample & 9,1 & 0,2 & 9,3 \\
\hline & SFI_B\&H & 8,7 & 0,4 & 9,1 \\
\hline \multirow{2}{*}{ Beech and Fir } & Sample & 3,3 & 4,0 & 7,3 \\
\hline & SFI_B\&H & 3,3 & 3,8 & 7,2 \\
\hline
\end{tabular}

If the regression models of this study, and regression models obtained by MATIC 1959, include in, the average (the same) size of the independent variables (the same habitat quality and share the same species in stock, roughly the same level of land coverage, we get the result - a conclusion that the average increment in the forests of beech and fir with spruce in limestone and dolomite, increasing by almost $1 \mathrm{~m}^{3} / \mathrm{ha}$ per year today, but more than 50 years ago, when the data were collected for Matićs research.

We do not know clear reasons for it. MATIĆ (1959) predicted an increase of the increment in the future, because at the time of his research, in the forests, was still significantly presented trees grown in virgin condition, with a small length and volume of the tree crowns.

It is possible, that there had been significant changes in the volumes of the tree crowns, due to intensive forest management after 50 years, but there have not been such investigations of tree crowns in recent years in $\mathrm{B} \& \mathrm{H}$.

Observed increase of the volume increment in these forests, could be result of of increasing $\mathrm{CO}_{2}$ in the atmosphere in recent decades. Hasenauer (2006), points out that in the last few decades there was a significant change in the conditions of growth of forest tree species in Europe. As the support of these conclusions, he has cited works by other authors (KENK ET ALL 1991, 1993, SPICKER 1996, KARJALAINEN ET ALL 1999). HASENAUER (2006) notes a positive trend in increasing the productivity of habitats in the southern parts of Northern Europe, Central Europe and some parts of southern Europe. 


\section{REFERENCES: - Literatura:}

BozALO, G. (1980): Zavisnost veličine zapreminskog prirasta bukve u čistim bukovim sastojinama i mješovitim sastojinama bukve, jele i smrče na području Bosne od veličine njene zapremine $i$ drugih taksacionih elemenata sastojine. Radovi Šumarskog fakulteta i Instituta za šumarstvo u Sarajevu, knjiga 24. sv 2. Sarajevo.

BozALO, G. (1985): Indikatorska vrijednost krivulja visina stabala bukovih sastojina pri produkcionom diferenciranju staništa Bukve na području Bosne. Šumarstvo i prerada drveta. str. $157-167$. Sarajevo.

Burger, H. (1950 ) Holz, Blattmenge und Zuwachs X. Die Buche. Mitt. der Schweiz. Anstalt für d. Forstl. Versuchswes 26:419-468.

Burger, H. (1951) Holz, Blattmenge und Zuwachs XI. Die Tanne. Mitt. der Schweiz. Anstalt für d. Forstl. Versuchswes 27:247-286.

Burger H (1952) Holz, Blattmenge und Zuwachs XII. Fichten im Plenterwald. Mitt. der Schweiz. Anstalt für d. Forstl. Versuchswes 28:109-156.

ĆIRIĆ M., Stefanović V., DRINIĆ P. (1971): Tipovi bukovih šuma i mješovitih šuma bukve, jele i smrče u Bosni i Hercegovini. Šumarski fakultet i Institut za šumarstvo u Sarajevu, Posebna izdanja br. 8, Sarajevo.

DRINIĆ, P. (1972): Dinamika rastenja i prirašćivanja bukve, jele i smrče u najvažnijim tipovima bukovo-jelovih šuma na Igmanu. Radovi Šumarskog fakulteta i Instituta za šumarstvo u Sarajevu, knj. 17, sv. 4-6.

IBRAHIMSPAHIĆ, A. (2013): Prirast i razvoj sastojina bukve, jele i smrče u GJ „Igman“. Doctoral dissertation. Šumarski fakultet Unoverzitet u Sarajevu.

Hair, J.F.JR., Anderson, R.E., TAtham, R.L. BLACK, W.C., 1995. Multivariate Data Analysis (with Readings). Fourth Ed., Prentice-Hall International, Inc., USA.

HaRtigan, J. A. (1975). Clustering algorithms. New York: Wiley.

Hasenauer, H. (2006): Sustainable Forest Management: Growth Models for Europe. Springer, Berlin, 398 pp.

Lojo, A., Beus, V., Mekić, F., KoprivicA, M., Musić, J., Treštić, T., Balić, B. ČABARAVDIĆ, A., HoČEVAR, M. (2008): Metodika druge inventure šuma na velikim površinama u Bosni i Hercegovini. Radovi šumarskog fakulteta u Sarajevu. Posebna izdanja br. 20, sv 1. str. 1-156.

Matić, V., Vukmirović, V., Drinić, P., Stojanović, O. (1963): Tablice taksacionih elemenata visokih šuma jele, smrče, bukve, bijelog bora, crnog bora i hrasta kitnjaka na području Bosne. Šumarski fakultet Univerziteta u Sarajevu. Posebna izdanja. Sarajevo.

MATIĆ, V. (1959): Taksacioni elementi prebornih šuma jele, smrče i bukve na području Bosne, Radovi Šumarskog fakulteta i Instituta za šumarstvo i drvnu industriju u Sarajevu, br 4. Sarajevo. 
PAVLIČ, J. (1966): Prirast stabala u zavisnosti od veličine krošnje i od njegovog položaja u sastojini. Radovi Šumarskog fakulteta i Instituta za šumarstvo u Sarajevu, knj. 10, sv. 1.

PECINA, M. (2006): Metode multivarijantne analize - osnove (interna skripta). Sveučilište u Zagrebu. Zagreb.

PINTARIĆ, K. (1991): Uzgajanje šuma. Šumarski fakultet u Sarajevu. Sarajevo.

SOKAL, R.R., ROHLF, F.J. (1995): Biometry The Principles and Practice of Statistics in Biological Research. Third edition. W. H. Freeman and Company. New York.

STATISTICA - TEXT BOOK (2008): Stat Soft, Inc. 1984 - 2008. http://www.statsoft.com/textbook/stathome.html.

Stefanović, V., Beus, V., Burlica, Č., Dizdarević, H., Vukorep, I. (1983): Ekološkovegetacijska rejonizacija Bosne i Hercegovine. Posebna izdanja br. 17. Šumarski fakultet u Sarajevu. Sarajevo.

Stefanović, V. Beus, V., Bozalo, G., Pavlič, J., Vukorep, I. (1983): Tipovi šuma smrče i bijelog bora, jele i smrče i smrče u Bosni. Posebna izdanja br. 15. Šumarski fakultet u Sarajevu, Sarajevo.

\section{SAŽETAK}

Cilj analiza, u ovom dijelu rada, je bio usmjeren na istraživanje postojanja uticaja pripadnosti sastojine različitim ekološko-vegetacijskim rejonima u Federaciji $\mathrm{BiH}$ (EV_R), te orografskih faktora: ekspozicije sastojine (EKSP), nagiba terena (Nagib) i nadmorske visine (VISINA) na veličinu zapreminskog prirasta sastojine (IVHA), unutar mješovitih sastojina bukve, jele i smrče u u Federaciji Bosne i Hercegovine (FBiH) na krečnjacima i dolomitima.

Da bi se mogao ispitati uticaj svih ovih faktora, prethodno je bilo potrebno eliminisati uticaje drugih faktora - strukturnih obilježja sastojine: udjela lišćara $u$ zalihe sastojina, udjela jele u zalihi, srednjeg prečnika sastojine po temeljnici, srednjeg prečnika četinara u sastojini, temeljnice sastojine, stepena prekrivenosti zemljišta krošnjama stabala sastojine te prosječene visine svih stabala prečnika $50 \mathrm{~cm}$, kao pokazatelja boniteta staništa. Istraživanja su izvršena na podacima od 799 sastojina, složenim metodama višestruke faktorske regresije,u prvom koraku i višestruke linearne regresije i analize varijanse istovremeno u drugom koraku (GLM-generalized linear models) računarskih programa Statistica i Statgraphics.

Rezultati su pokazali da ekspozicija sastojine nema značajan uticaj na veličinu zapreminskog prirasta sastojine, dok ekološko-vegetacijski rejoni imaju statistički značajan uticaj na veličinu istog. Konstatovano je da postoji logičan raspored u prostoru rejona koji se međusobno ne razlikuju u veličini zapreminskog prirasta sastojine (slika 2), i da se razlike koje postoje u veličini zapreminskog prirasta, između pojedinih rejona mogu tumačiti preko karaktera njihove klime. Značajan je i uticaj 
nadmorske visine. Sa porastom nadmorske visine smanjuje se veličina godišnjeg zapreminskog prirasta pri istim prosječnim veličinama ostalih obuhvaćenih faktora (nezavisnih varijabli) uključenih u regresioni model.

Rezultat analiza su složeni matematički modeli, koji se mogu koristiti i za procjenu veličina zapreminskog prirasta sastojina sa visokim stepenom objašnjenja promjena $\left(\mathrm{R}^{2}=0,79\right) \mathrm{u}$ različitim uslovima strukturne izgrađenosti i položaja sastojine $\mathrm{u}$ prostoru. Ako se uvrste iste veličine taksacionih elemenata sastojina, uz prosječne veličine orografskih parametara u matematički model, dobije se rezultat koji ukazuje da je godišnji zapreminski prirast u ovim šumama, danas, veći za oko $1 \mathrm{~m}^{3} /$ ha, nego prije 50 godina, kada je MATIĆ (1959) vršio vrlo slična istraživanja u istim šumama. Razlozi se mogu tražiti u promjeni dužina krošanja stabala. prevođenjem šuma iz prašumskih u privredni oblik. Naime, u vrijeme istraživanja od 1951 do 1958, koje je obavio MATIĆ (1959), šume u BiH su još uvijek imale prašumske karakteristike u velikoj mjeri, što se karakterisalo krošnjama stabala značajno manje veličine, nego stabala istih dimenzija odraslih u šumama u kojima se dugo godina vršene preborne sječe. Povećanje prirasta je vjerovatno i posljedica značajnog povećanja $\mathrm{CO}_{2} \mathrm{u}$ atmosferi tokom nekoliko posljednjih decenija, jer je sličan trend povećanja prirasta šuma registrovan u Evropi (HASENAUER 2006). 